\author{
Aleksander Nawarecki \\ Uniwersytet Śląski w Katowicach \\ (iD http://orcid.org/0000-0001-7271-2080
}

\title{
Strupki (etiuda literacko-dermatologiczna)
}

\section{Scabs: A Literary-Dermatological Study}

Summary: This essay is devoted to the titular "scabs" - wounds usually associated with childhood, the effects of minor injuries, mainly to the knees and elbows, sustained while playing. These are unique wounds, associated more with joy than with pain. In Polish, "scab" [strupek] is a diminutive form of the word "corpse" [trup], which is awe-inspiring and disgusting. Such a combination of the delicacy of grammatical diminutive with the aesthetics of deadly decay is surprising. That is why this word is used carefully in Polish, and it is an act of courage to place it in a title of a novel. This risk was taken by Paulina Jóźwik in her prose debut (2019), a story about the maturation of a young woman, where the symbolism of the titular Scabs (Strupki) reflects the bitter-sweet experience of the family home.

Keywords: wound, disgust, Paulina Jóźwik, a story of maturation, Polish women's literature

Streszczenie: Tematem eseju są tytułowe „strupki”, rany zwykle kojarzone z dzieciństwem, efekt drobnych urazów, przeważnie kolan i łokci, doznanych w trakcie zabaw. Chodzi o wyjątkowe rany, które w pamięci kojarzone są raczej z radością niż bólem. W języku polskim "strupek” jest zdrobniałą formą słowa „trup", budzącego grozę i wstręt. Takie połączenie delikatności gramatycznego spieszczenia z estetyką śmiertelnego rozkładu jest zaskakujące, dlatego słowo to ostrożnie używane jest w polszczyźnie, a zatytułowanie nim powieści stanowi akt odwagi. To ryzyko podjęła Paulina Jóźwik w swoim prozatorskim debiucie (2019), opowieści o dojrzewaniu młodej kobiety, w której symbolika tytułowych Strupków oddaje gorzko-słodkie doświadczenie domu rodzinnego.

Słowa kluczowe: rana, wstręt, Paulina Jóźwik, opowieść o dojrzewaniu, polska literatura kobieca 
Na kolanie pieniła się woda utleniona P. Sikora: Papa danse

1.

Ranny nigdy nie byłem i Bogu dziękować nikt z moich bliskich też nie, przynajmniej w mojej przytomności, bo ojciec w czasie wojny doznał jednak paru poważnych urazów, które sportowo mianował „kontuzjami”. Ran też nie opatrywałem, a jeśli kiedyś zetknąłem się z poważnie okaleczonym ciałem, to wolałbym nie mówić o tym głośno, a już na pewno nie pisać. I właśnie dlatego we własnych tekstach, które wymęczyłem w znoju i bólu, bodaj nigdy nie użyłem słowa "rana" i niech tak pozostanie.

Nie bacząc jednak na to zasklepienie pamięci i pisarski skurcz, redaktorka "Rany" kusiła mnie tymi mniej więcej słowami: „A kiedy byłeś mały, czy nie miałeś takich małych ranek, słodkich raneczek, które nie zdążyły zaboleć, a szybko się goiły, tym szybciej im czulej całowała je mamusia, babcia chuchała, koleżanka z podwórka spluwała magicznie, pies chciał lizać, a kolega obsikać? Jak to się na Śląsku mówiło - boloki - czy nie ślicznie? Pamiętasz, pewnie nie zapomniałeś, bo na pewno mimo zakazów, zdrapywałeś strupki...".

Trudno nie ulec urokowi bajki o tym, jak byliśmy mali, Zbigniew Herbert wiedział o tym najlepiej, a Samuel Linde zapamiętał przysłowie: „Słodki strup najczęściej dzieciom się przytrafia”" będzie jednak bajki, nie będzie słodyczy, nie poniesie nas nostalgia, bo cały ten uroczy, czuły dyskurs psuje jedno słowo - "strupek". Dziwnie brzmi to zdrobnienie, bo w "strupku” słychać "strupa”, a w "strupie” straszy "trup”. Linde, a za nim Aleksander Brückner dopowiadają, że "strup" to prasłowo, którego sens u różnych Słowian waha się między „raną”, „sińcem” i „blizną”, zaś u Serbów może oznaczać także ,jad"2. I właśnie ten jadowity, mdły, słodkawy, czyli trupi, zapach brzydzi mnie na tyle, że wolałbym nie zdrabniać "strupa" ani tym bardziej „trupa”. Na to mógł sobie pozwolić Juliusz Słowacki w fazie przedmistycznej oraz nastroju groteskowym, kiedy odmieniał w kółko swoje "trupków girlandy" (trupek - trupeczek

${ }^{1}$ S.B. Linde: Słownik języka polskiego. T. 5. Zakład Narodowy im. Ossolińskich, Lwów 1859, s. 479.

2 A. Brückner: Słownik etymologiczny języka polskiego. Wiedza Powszechna, Warszawa 1985, s. 521. 
- trupiątko) ${ }^{3}$. Ale czym bawił się autor Piasta Dantyszka, tym ja nie potrafię i nadziwić się nie mogę, skąd wzięło się to słowo $\mathrm{w}$ polszczyźnie, bo straszyło mnie nawet $w$ innych językach. Zapomnieć nie mogę wrażenia sprzed lat, kiedy za młodu, jadąc autostopem do Kopenhagi, usłyszałem nazwy okolicznych miejscowości - Kastrup, Gadstrup, Glostrup... Co znaczy „strup”, pytałem nieśmiało miejscowych, bo tylko ta brzydka sylaba przebijała się do uszu ze strumienia obcej mowy. Zdziwieni Duńczycy odpowiadali, że nie ma takiego wyrazu. Kiedy teraz wracam do tej kwestii, bliski jestem domysłu, że pytałem o nazwy geograficzne, których geneza wiąże się z rejonami rolniczymi i hodowlą bydła, bo cząstka "trup" w języku duńskim (i szwedzkim też) oznacza 'stado'. Ten sam niemiły źródłosłów pobrzmiewa w polskiej „trupie”, niefortunnie zapożyczonej $\mathrm{z}$ francuskiego na określenie grupy (stada?) komediantów i cyrkowców. Nie należy się dziwić tej cyrkulacji przykrych wrażeń, bo - jak powiada Julia Kristeva -

Trup to najobrzydliwszy ze wszystkich odpadów. [...] Trup - oglądany bez Boga i nie z perspektywy nauki - to szczyt wstrętu. To śmierć pustosząca życie. Wy-miot. To odrzucony, od którego nie da się uwolnić, przed którym nie ma obrony, tak jak przed przedmiotem. Wyobrażona dziwność i realne zagrożenie, wzywa nas i w końcu pochłania. [...] Wstrętne jest to, co zaburza tożsamość, system, $\mathrm{lad}^{4}$.

2.

Odkładam na bok traktat o Potędze obrzydzenia i sięgam po współczesną polską powieść, której kolorowa okładka zdaje się usuwać wszelkie odruchy wstrętu. Z ciemnego tła wyłania się lśniąca zieleń liści i połyskująca czerwień owoców podobnych do borówek albo głogu, po których wolno spodziewać się słodko-gorzkiego aromatu. Tak wygląda debiutancka książka Pauliny Jóźwik, opublikowana w roku 2019 przez wydawnictwo Znak, a jej witalną świeżość podkreśla reklamowe hasło podpisane przez renomowaną pro-

${ }^{3} \mathrm{O}$ makabrycznych zdrobnieniach i spieszczeniach piszę w szkicu Czułe słówka Słowackiego. Zob. A. Kotliński, A. Nawarecki: Dialog troisty. Colloquia o Juliuszu Słowackim. Instytut Badań Literackich PAN, Warszawa 2019, s. 137-139.

${ }^{4}$ J. Kristeva: Ujęcie wstrętu. W: Eadem: Potęga obrzydzenia. Esej o wstręcie. Tłum. M. Falski. Wydawnictwo Uniwersytetu Jagiellońskiego, Kraków 2008, s. $9-10$. 
zaiczkę - „Oto narodziła się pisarka. JOANNA BATOR” ${ }^{5}$. Trudno przeoczyć ten blurb, bo - wbrew zwyczajom - umieszczony został na I stronie okładki, tuż nad nazwiskiem autorki, wyłaniając się z kłębowiska gałązek (dyskretnie zasłaniających tytuł). Reklamowy slogan zapowiada "narodziny gwiazdy”, więc akcent pada na życie, co współgra z florystyczną dekoracją, zwłaszcza z czerwienią owoców przeświecającą także na brzegach twardej oprawy książki i rozlewającą się na ostatniej stronie okładki, gdzie stanowi tło fotografii autorki. Karminowa czerwień rozbłyskuje po raz trzeci na ustach młodej kobiety w kwiecistej sukni, sportretowanej na tle parkowej zieleni. Debiutantka uśmiecha się delikatnie, bo - jak głosi napis pod jej owalnym portretem - obiecuje czytelnikom „opowiedzianą ciepłym szeptem powieść o godzeniu się z życiem, pamięci i rodzinnym domu, którego głos pozostaje w nas zawsze"

Zaintrygowany uwodzącą szatą graficzną książki, ciekaw byłem, kto ją zaprojektował, kto kryje się za sygnaturą - Inna Sinano? Okazało się, że nie jest nazwisko artystki, lecz nazwa agencji fotograficznej sprzedającej motywy zdobnicze, które tutaj zręcznie zaadaptowała Anna Niklewicz. Efektowna oprawa książki nie jest zatem wyrafinowanym artefaktem, ale dekoracją stanowiącą element strategii reklamowej zaadresowanej do wyraźnie "stargetowanego" klienta. Zapewne idzie o czytelników, a zwłaszcza czytelniczki literatury popularnej, lecz o wyrobionym smaku, wszak w serii wydawniczej Proza PL wcześniej ukazały się powieści Magdaleny Tulli, Anny Cieplak, Michała Witkowskiego, Jacka Dehnela i - jak łatwo się domyśleć - Joanny Bator. Wydawca mianuje je „bestsellerami”, a jednak ich okładki nie są tak kwieciste jak w przypadku książek Jóźwik i Bator (w tej samej serii), co zdaje się sugerować estetyczne powinowactwo pisarstwa Joanny i Pauliny. Gwałtownie splątane gałęzie, pędy i liście sugerują skomplikowane, a czasem mroczne relacje między ludźmi, co potwierdza umieszczone obok streszczenie:

Hanna Maj żyła po cichu, a jej życie skończyło się na długo przed śmiercią. Choroba sprawiła, że przestała rozpoznawać żyjących, za to coraz częściej odwiedzali ją zmarli.

Pola wraca do rodzinnego domu dzień przed pogrzebem babki. Chce odzyskać wspomnienia, które straciła Hanna. Wchodzi

${ }^{5}$ Por. P. Jóźwik: Strupki. Znak Litera Nova, Kraków 2019.

${ }^{6}$ Ibidem, IV strona okładki. 
w pamięć jak w pokutę. Co się stało z bratem matki, który pewnego dnia zniknął? Skąd w siostrze tyle złości i goryczy?

Czy Pola zdoła odkryć to, o czym wszyscy w rodzinie milczą??

Czytelnik dowie się z kolejnych kart, że choć babcia Hania nosiła wiosenne nazwisko, to nie uchroniło ono Pani Majowej od mrocznych doświadczeń, a jednak jej wnuczka pragnie rozjaśnić te mroki, co słychać w ostatnim akapicie, tuż przed słowem KONIEC:

To jest mój dom. Nawet gdy jest ciemny. [...] Mój dom to wielkie dziecko, które noszę ze sobą na plecach. Karmię je życiem, a ono kurczowo trzyma się mnie za szyję i szepcze, że bez niego nie istnieję ${ }^{8}$.

Życiodajna opowieść o domu i dzieciństwie działa kojąco, a jeśli została opowiedziana „ciepłym szeptem” (jak zapewnia wydawca), to rosną szanse na czytelniczy sukces. Owszem, ale pod jednym warunkiem: trzeba koniecznie zasłonić, schować, a przynajmniej osłabić wymowę tytułu. Bo czy bestsellerem może być książka zatytułowana Strupki?

3.

Starałem się pokazać, jak projektant okładki książki Pauliny Jóźwik próbował roślinnymi motywami i jaskrawymi barwami odwrócić uwagę od jej tytułu namalowanego białą farba, tak wybielonego, by nie rzucał się w oczy czytelnika. Ciekaw jestem, czy wydawca namawiał debiutantkę do zmiany ryzykownego tytułu, a jeszcze bardziej ciekawi mnie jej determinacja na tym polu. Być może młoda autorka (rocznik 1988), która „wychowała się na śląskim blokowisku"9, właśnie tam zyskała podwórkową, czy raczej: „placową", górnośląsko-plebejską twardość i nie wstydziła się boloków, choćby po polsku brzmiały tak niewymownie. A może to wieś, w której mieszkali jej dziadkowie, nauczyła ją surowego stosunku do ciała? Nie wiadomo, czy dziecięce rany oraz psychiczne urazy szybciej się zabliźniają w mieście czy na prowincji, ale "trupie" brzmienie słowa raczej nie sprzyja terapii. Strupki dźwięczą tak nie-

7 Ibidem.

${ }^{8}$ Ibidem, s. 251.

${ }^{9}$ Ibidem, IV strona okładki. 
pokojąco, że po tekście wolno spodziewać się prowokacji - estetyki groteski, subwersyjności, może poetyki queeru, co jakoś współgra z patronatem Joanny Bator. Jednakże dla Pauliny Jóźwik, która „najchętniej pisze o wsi" ${ }^{10}$, bliższy zdaje się model prozy kobiecej osadzonej $\mathrm{w}$ realiach polskiej prowincji, konwencja wypracowana przez Wiolettę Grzegorzewską, Aleksandrę Zielińską czy Weronikę Gogolę $e^{11}$. Nurt opowieści o dojrzewaniu, tak silnie obecny w ostatnich latach, mógł stanowić wzór dla Strupków, pomimo że brakuje im ironii Gugułów, czarnego humoru Po trochu, drapieżności Kijanek $i$ kretowisk. Może dopiero ów transgresyjny tytuł uwiarygodniał wspomnieniową narrację niby brzydkie znamię albo bolesne piętno? Nie chciałbym wytykać debiutantce jakichkolwiek słabości, raczej chciałbym premiować jej odwagę czy desperację, a choćby nawet pomyłkę w wyborze nagłówka, który przecież mógł zniechęcić niektórych czytelników ${ }^{12}$.

4.

Najwyższa pora, by zacytować Strupki i przywołać to miejsce w tekście, które zdaje się najbliższe tytułu. Kiedy zbliżamy się powoli do końca powieści, jej główna bohaterka, Pola, strapiona rozwojem akcji pozwala sobie na chwilę samotności, uspokojenia, a nawet relaksu. Beztrosko wskakuje na rower i gna przed siebie co sił:

Chciałam się rozpędzić. Naciskałam na pedały coraz mocniej i mocniej, aż w końcu prułam jak szalona. Zamknęłam oczy. Zdjęłam stopy z pedałów i wyprostowałam nogi. Wiatr otulał mi policzki. Muskał powieki. Gładził ramiona. Po kilku sekundach kierownica drgała i traciłam panowanie nad rowerem. Wtedy ot-

${ }^{10}$ Ibidem.

${ }^{11}$ Por. W. Grzegorzewska: Guguły. Wydawnictwo Czarne, Wołowiec 2014; W. Gogola: Po trochu. Książkowe Klimaty, Kraków 2017; A. Zielińska: Kijanki i kretowiska. Wydawnictwo W.A.B. - Grupa Wydawnicza Foksal, Warszawa 2017.

${ }^{12} \mathrm{~W}$ recenzjach i komentarzach $\mathrm{w}$ sieci nie trafiłem jednak na krytykę „niesmacznego" tytułu; czytelnicy uchwycili jego symboliczny sens, co najlepiej ilustruje opinia internautki Izy (29.08.2020): „Strupek sugeruje gojenie, nie do końca, jeszcze jest uformowany skrzep, twardy, stymulujący do drapania, zrywania przez co blizna powstaje większa i bardziej wyraźna. Wtedy pamiętamy, że w tym miejscu była rana i okoliczności jej powstania". https://lubimyczytac.pl , ksiazka > strupki [dostęp: 10.04.2021]. W cytacie zachowano oryginalną interpunkcję. 
wierałam oczy, ściskałam rączki kierownicy i zabawa rozpoczynała się na nowo. Pedałowałam z całych sił. Nie przeszkadzało mi skrzypienie sprężyn pod siodełkiem. Podążałam za szumem opon. Kamyczki wpadały między szprychy, ale zasuwałam dalej. Blues dyszał obok mnie, a ja puszczałam kierownicę i jechałam bez trzymanki.

Rower pochylił się nagle i wylądowałam z impetem na ziemi. Kierownica się przekręciła. Dzwonek zadźwięczał, jakby właśnie wyzionął ducha. Blues kręcił się obok i nie wiedząc, co się dzieje, zaczął szczekać. Kiedy go odgoniłam, położył się przy rowerze i nie zwracał już na mnie uwagi. Podniosłam się. Zobaczyłam zdartą skórę na kolanie. Wyglądało, jakby przejechała po nim tarka. W ranie gromadził się piach. Próbowałam go wyciągnąć, ale za bardzo piekło.

Będę żyła, pomyślałam. Otrzepałam się z kurzu, wsiadłam na rower i ruszyłam, bo byłam znowu dzieckiem. Dziewczynką, która jeszcze nie wie, co to znaczy mieć świadomość ${ }^{13}$.

Jaka piękna katastrofa! Tak chciałoby się zawołać w komentarzu do tej sceny, do transowej zabawy, czy raczej gry typu ilinx, której celem jest oszołomienie, utrata przytomności i euforyczny "odlot"14. A co za tym idzie - wędrówka w czasie - mentalny powrót do dzieciństwa. Efektem, śladem i pamiątką tej przygody oraz psychicznej metamorfozy jest drobna rana na ciele:

Obejrzałam swoje kolano. Kilka czarnych drobinek ziemi tkwiło głęboko $\mathrm{w}$ ranie i wiedziałam, że zostaną ze mną na zawsze. Przyłożyłam babkę do rany i usiadłam na brzegu. [...] Podciągnęłam spódnicę i przeszłam przez rzekę. Gdzie zniknął strach ${ }^{15}$

Symboliczne przejście przez wodę oczyszcza i daje spokój, Paula wraca "do siebie”, więc może teraz najdosłowniej wrócić do domu, do siostry Ireny, z którą wcześniej nie potrafiła się porozumieć:

- Co ci się stało? - Irka spojrzała na moje zdarte kolano.

- Nic. Popatrzyłam na zasklepioną już ranę. - Myślisz, że będzie blizna?

${ }^{13}$ P. Jóźwik: Strupki..., s. 192.

${ }^{14}$ Por. R. Caillois: Żywioł $i$ ład. Tłum. A Tatarkiewicz. Państwowy Instytut Wydawniczy, Warszawa 1973, s. 325.

15 P. Jóźwik: Strupki..., s. 193. 
- Nie wiem. Najpierw zrobi się strupek, a jak zejdzie, to sama zobaczysz. A co z tym zielskiem?

- No mówię ci przecież, że narwałam rumianku na włosy.

A może narwałam go na serce? ${ }^{16}$

To jedyne miejsce w powieści, w którym przywołany jest tytułowy strupek. Ujmująca prostota tego epizodu może zbyt pochopnie została „osłodzona” aromatem rumianku i skurczem serca, ale rekonstrukcja dzieciństwa, w które wjeżdża się „bez trzymanki” i pada na kolana, by doznać małej iluminacji, a potem zrywa się strupki na gojącym kolanie - to obraz nieomal archetypowy. Zapewne nie raz pojawił się na kartach powieści dla młodzieży, choć moja pamięć jakoś nie podsuwa mi obtłuczonych kolan dzieci z Bullerbyn, Leszczynowej Górki albo Czarnego Podwórza17.

5.

A jednak lektura przywołanego fragmentu Strupków brzmi swojsko, niechybnie przypomina „smaki dzieciństwa”, jakie znamy chyba wszyscy, więc nie warto silić się na osobisty, odrębny komentarz. Bo zdaje mi się, że każdego lata wszyscy mieliśmy strupy na kolanach, czasem też na łokciach, ale na kolanach - zawsze. Od wczesnej wiosny do jesieni. Zawsze i nieuchronnie. Co roku. Jakby to była część przyrodniczego cyklu, a nawet roku liturgicznego, bo pamiętam, że już na nabożeństwach majowych, a potem na czerwcowych trudno mi było klęknąć. Nie wnikam w rozmaite szczegóły, choćby związane z polewaniem boloków wodą utlenioną w gabinecie higienistki, nie przywołuję też indywidualnych strategii dłubania w ranach. Intryguje mnie coś innego: jak to się stało, że w pewnym momencie (nieuchwytnym, niezapamiętanym) jakby samoistnie przerwał się ten cykl? Wszak od dawna, mimo nadchodzących wiosen, nie miewam otartych kolan, nawet jednego. A przecież nie omijają mnie inne rany, guzy, wrzody, zadrapania, nie mówiąc o krostach czy liszajach, a zdarzają się nawet złamania, których fortunnie uniknąłem w dzieciństwie. A jednak na kolanach ani na łokciach nie noszę już sezonowych ran. Żegnaj strupku!

\footnotetext{
16 Ibidem, s. 195.

${ }^{17}$ Nie potrafię odtworzyć dziejów tego motywu w literaturze dziecięcej, ale za przełomowy można uznać rok 2014, kiedy wydawnictwo Tako w serii Mam Ciało opublikowało przekład japońskiej książeczki obrazkowej dla najmłodszych Gen-ichiro Yagyu pt. Strupek.
} 


\section{Bibliografia}

Brückner A.: Słownik etymologiczny języka polskiego. Wiedza Powszechna, Warszawa 1985.

Caillois R.: Żywioł i ład. Tłum. A Tatarkiewicz. Państwowy Instytut Wydawniczy, Warszawa 1973.

Gogola W.: Po trochu. Książkowe Klimaty, Kraków 2017.

Grzegorzewska W.: Guguty. Wydawnictwo Czarne, Wołowiec 2014.

Jóźwik P.: Strupki. Znak Litera Nova, Kraków 2019.

Kotliński A., Nawarecki A.: Dialog troisty. Colloquia o Juliuszu Słowackim. Instytut Badań Literackich PAN, Warszawa 2019.

Kristeva J.: Potęga obrzydzenia. Esej o wstręcie. Tłum. M. Falski. Wydawnictwo Uniwersytetu Jagiellońskiego, Kraków 2008.

Kristeva J.: Ujęcie wstrętu. W: Eadem: Potęga obrzydzenia. Esej o wstręcie. Tłum. M. Falski. Wydawnictwo Uniwersytetu Jagiellońskiego, Kraków 2008, s. 7-35.

Linde S.B.: Słownik języka polskiego. T. 5. Zakład Narodowy im. Ossolińskich, Lwów 1859.

[Opinie internautów]. https://lubimyczytac.pl > ksiazka > strupki [dostęp: 10.04.2021].

Yagyu Gen-ichiro: Strupek. [Przekł. K. Radomska-Nishii]. Tako, Toruń 2014.

Zielińska A.: Kijanki i kretowiska. Wydawnictwo W.A.B. - Grupa Wydawnicza Foksal, Warszawa 2017.

Aleksander Nawarecki - profesor, pracownik Uniwersytetu Śląskiego; historyk i teoretyk literatury, edytor i komentator poezji ks. Baki (Czarny karnawat, 1991), autor książek o przedmiotach, roślinach i zwierzętach w literaturze (Rzeczy i marzenia, 1993; Pokrzywa, 1996; Parafernalia, 2014), o twórczości romantyków (Mały Mickiewicz, 2003; Dialog troisty. Colloquia o Juliuszu Słowackim, 2019 - wspólnie z Andrzejem Kotlińskim), a także esejów o Śląsku (Lajerman, 2011). Współautor podręcznika szkolnego Przeszłość to dziś (2003-2020), współredaktor serii Miniatura i mikrologia literacka (2000-2003) oraz Ilustrowanego stownika terminów literackich (2018).

e-mail: aleksander.nawarecki@us.edu.pl 